\title{
KÁNON ÉS BEFOLYÁS Az irodalmi autoritás kérdéséhez
}

\author{
Bármit gondoljunk is a nyugati \\ kánonról, az biztos, hogy nem \\ a társadalmi megváltás programja. \\ (Harold Bloom: The Western Canon)
}

\section{Kánoni létmód és irodalom}

A kánon fogalma a 18. század óta azon kimagasló művek többnyire zárt körét jelöli, amelyeket az irodalomra nézve és annak fennállása szempontjából - érték, jelentőség, hatás vagy (el)ismertség okán - megkerülhetetlennek s ezért bizonyos mértékig kötelező érvényűnek tekintünk. Az ugyan igaz, hogy az irodalomhoz tartozás ismérvei maguk is eredendően történetiek (az eruditiónak a 17. század végéig uralkodó kritériumai elsősorban tanult írni tudásként, kiművelt írásmódként határozták meg a szövegeknek azt a csoportját, amelyek egy része mai nézetből - de még nem az irodalmiság 19-20. századi indexeivel - „szép literaturának"1 bizonyult). Az irodalom fogalmának változásai azonban azzal még, hogy eleve érvénytelenítik valamely idötlen irodalmiság gondolatát, nem számolják föl a kiemelkedő művek (klasszikusok) korszakokat átívelö értékeinek irodalmi indokolhatóságát. Ebben az értelemben

\footnotetext{
1 A fogalom/szókapcsolat Kazinczytól származik s valószínűsíthető, hogy a Pályám emlékezetének egy Rádayakról szóló, 1808. március 8-i életrajzi feljegyzésében bukkan fel elöször (http://deba.unideb.hu/deba/kazinczy_muvei/text.php?id=kazinczy_onelet_0112_k\&hi=sz\%C3\%A9p\%20literatura). Az adatért Debreczeni Attilának tartozom köszönettel. Az, hogy a klasszikus (mai értelemben vehető) irodalmi kánonok a 19. század termékei, alapvetően azzal függ össze, hogy az európai (humanizmus kori eredetü) literatura fogalom ekkorra vált meg a maga humán tudományokra is kiterjedő jelentésétől. Lehetővé téve az irodalom olyan ismérveinek kánoni érvényesítését, amelyek között - egyéb, legitimációs, identitásképző és értékorientáló funkciók mellett - kitüntetett szerep jut annak a nyelvművészeti megalkotottságnak, amely korokon átívelő gyönyörködés („,csudállás”) tárgyává teszi a szöveget: „Csokonaynak - írja Kazinczy egy 1805-ös levélben Cserey Farkasnak - némelly munkáji olly szépek, (illyen a' három ódája a’ Lepéhez, Reményhez, és a’ Szemrehányás) hogy a’ Magyar Litteratura soha nem fog fó grádicsára fel lépni, a’ mellyben azokat csudállás nélkül olvassák." KAzINCZY Ferencz Összes müvei. Levelezés, III., MTA, Budapest, 1892, 302. Nálunk a fentebb „stílnemben”, ízlésben és művelésben megalapozott kánoni gondolat atyja, Kazinczy neve fémjelzi ezt a fordulatot, amely „egy egészen újszerű, modern irodalmiság kiforrását segítette elő: a vallás és eruditio jegyében álló régi irodalmiság helyére most állhatott oda igazán a modern szépirodalom". Horváth János, A XIX. század fejlödéstörténeti elözményei = Uő. Irodalomtörténeti munkái, II., Osiris, Budapest, 2006, 612 .
} 
a modernségnek az újkori irodalmiság ismérvei (fikció, innováció, eredetiség) jegyében álló, közelebbről pedig a Nietzsche fiziológiai esztétikája és Mallarmé abszolút költészete közti térben kialakult műalkotáseszménye a maga autonóm önmagára vonatkozása és a formai tökélyben kiteljesedő stabilitása ellenére éppúgy nem ássa alá a kánoni örökség tekintélyét, ahogy a stíluspluralizmusok, az avantgárd szubverziók és a posztmodern utólagosság kora sem szolgáltatja ki a tetszőlegességnek az irodalmi mibenlét - mindig kánonreleváns - kérdését.

Az az irodalmi episztémé, amelynek müalkotás-fogalma felől ma a kánonról gondolkodunk, nem anyag és forma, jel és jelentett, igazság és szépség elválasztottságának tapasztalati alapzatán nyugszik, azaz nem az esztétikai megkülönböztetés doktrínájára épül. „A műalkotás nem jelent valamit - írja erről Gadamer -, nem utal jelként egy jelentésre, hanem úgy mutatkozik meg saját létében, hogy a szemlélő igényli a nála való időzést. Olyannyira önmaga van jelen, hogy az, amiből vétetett, a kő, a festék, a zenei hang, a szó csak benne nyeri el tulajdonképpeni jelenvalólétét." ${ }^{2}$ A műalkotás maga így nem gondolható el a benne megnyilatkozó, megtörténő igaztól függetlenül, ami azt jelenti: az igaz tapasztalata nem afféle hordozott „tartalma” vagy „járuléka” valamely forma(esztétika)i hatásnak. „Nem az előre megformált átformálása, nem az előzetesen már létező leképezése alkotja a művészet lényegét, hanem a kivetülés, ami által valami új mint igaz jön elő."3

Ez az igaz(ság) művé válásában megalapozott müalkotás-értelmezés természetesen az igaz és a szép elválaszthatatlansága ellenére sem veszíti el kapcsolatát azzal a formával, amelyen minden szép(ség) nyugszik. Ami annak biztosítéka, hogy az esztétikai tapasztalatban a szép mindig alakot öltve, de nem formalista elöírások uralma alatt történhetik meg igazként. Másképpen fogalmazva: nem olyan retorikai-poétikai vagy szerkezeti formakészletek „alkalmazásával” materializálódik, amelyek úgy (és olyan eszköziséggel) tartoznának eredendően az irodalmiság körébe, hogy ezért alkalmasak volnának az irodalom lényegének formális meghatározására. Az önmagában álló, önmagán nyugvó autonóm műalkotás eszméje éppen azért nem válhatott semmiféle (a környezetétől elkülönült) hermetikus irodalomfölfogás hivatkozási pontjává, mert művészeti tapasztalatának szerkezetén keresztül függesztette föl az irodalmiság valamely alaki lényegének megragadhatóságát. Az e tekintetben legradikálisabbnak mondható - de itt strukturalista hagyományt követő - Paul de Man is úgy próbálta a retoricitással azonosítani az irodalmiságot, hogy a figuratív-retorikai potenciál érvényesülését magát is az olvashatóság történő allegóriáihoz kötötte. ${ }^{4}$

2 Hans-Georg Gadamer, Bevezetés Heidegger A műalkotás eredete cimü tanulmányához, ford. Bacsó Béla = Martin Heidegger, A müalkotás eredete, ford. Bacsó Béla,Európa, Budapest, 1988, 21.

3 Uo., 29.

4 „,[H]abár ez talán már távolabb vezet a közhasználattól, én habozás nélkül magával az irodalommal azonosítanám a nyelv retorikai, figurális potenciálját." Paul DE MAN: Az olvasás allegóriái, ford. Fogarasi György, Ictus-JATE, Szeged, 1999, 23. Lásd még Uo., 29. 
Így tekintve a modernség episztémétörténeti feltételei között sem a kánonképződésnek, sem a kánonértelmezésnek nincsenek olyan kényszerítő előírásai/körülményei, amelyek olyan konstitutív formaeszmékhez kötötték az irodalmiságot, mint (Gottschedtől Kazinczyig) a 17-18. századi szabálypoétikák. A fenti, irodalomszemléleti okokból már eleve is komplexebb lesz az amúgy is összetett kánonképződés egész folyamata: úgy is fogalmazhatnánk, a kánonok története során a modernség teremtette meg talán a legrugalmasabb és legnyitottabb körülményeit egy soktényezős, temporális konfigurációban alakuló kánonképződésnek, ideértve - a legkülönfélébb szinteken Barbara Johnsontól Edward Saidig vagy Leslie Fiedlertől Robert Darntonig - a kánon felnyitására, radikális újraírására, sőt legalább négy évtizede a felszámolására irányuló törekvéseket is. Megjegyzendő itt, hogy bármily népszerü volt is egy ideig a kánon elvi megszüntetésének néhány programja, e keretek közti tárgyalásuk azért látszik szükségtelennek, mert a kanonizáció (vagy valamely fokú kanonizáltság) olyan szorosan kötődik az irodalom létmódjához, hogy az ügyben sem volna könnyủ állást foglalni: az irodalom igényli-e a kánoni hordozottságot, vagy pedig ahogy a Paul de Man kánonfelfogását értelmező David Martyn következtet - voltaképpen „nem a kánon [áll] sajátosan irodalmi szövegekből, hanem fordítva: az irodalom a »kánon« folyamatának egy funkciója”. Egészen radikálisan szólva: kánon és annak autoritása nélkül már csak azért sem lehetséges irodalom, mert a kánoni létmód valamely - alternatív vagy akár periferiális - formája nélkül egyetlen szöveg sem bizonyulhat irodalminak. Az irodalom - amely távolról sem azonos a külső műfaji-poétikai formajegyeket felmutató szövegek beláthatatlan tömegével - ennek értelmében csupán a kánon médiumán keresztül válik egyáltalán láthatóvá. Ez a közvetitett létmód a maga összetettségében ugyanakkor szinte szétválaszthatatlanul mutat vissza a maga távolabbi, diszkurzív és diszpozitív eredetére is. És minthogy egy szöveg irodalomhoz tartozásának ismérvei csak a fennálló kánon ról olvashatók le, egyetlen új szövegnek sincs módja arra, hogy - példásan mutatja ezt a magyar modernségben Babits és Kassák vitája - az uralkodó kánoni értékformáktól függetlenül, azt megkerülve vagy figyelmen kívül hagyva, tehát ne ahhoz képest határozza meg a maga mégoly „eredeti” irodalmiságát is. ${ }^{6}$ Ami azzal jár, hogy minden új szöveg csak az érvényes kanonikus

5 David Martyn, Az olvashatatlan autoritása, ford. Kulcsár-Szabó Zoltán = Irodalmi kánon és kanonizáció, szerk. Rohonyi Zoltán, Osiris, Budapest, 2001, 235.

6 Babitscsal vitatkozva Kassák sem az avantgárd legszembetűnőbb formai, technikai vívmányait (szabadvers, materializáció, montázsszerűség stb.) vagy mozgalmi szerveződését tekinti döntőnek, hanem az „új versnek" azt a képességét, hogy az eltérő irányú élménytartalmak esztétikai egyenértéküsége jegyében válik saját előzményeinek folytatójává: „Még azt is szeretném korrigálni, hogy tévedésből sem vagyunk kimondottan szimultaneisták, és semmiféle isták és izmusok nem vagyunk, és új irodalmi iskolát sem akarunk csinálni, csak a "jó» szó átértékelésében jó költők akarunk lenni, azaz jó költeményeket szeretnénk a legfrissebb olvasógeneráció elé adni. És bízunk az akaratunkban, mert az előttünk futók $s$ a már pihenésre fáradtak kezéből mi is átvettük az örökégő fáklyát, s csak az a különbség köztünk, hogy mi másfelé érezzük a célba vezető utat, mint ők, és más, színesebb, gazdagabb hangszereléssel akarjuk kidobni magunkból azt, ami müvészet." 
ismérvekre visszavonatkozva tarthat igényt irodalmi - s ennyiben ismét szükségszerüen kánoni - létrangra. A kánonkritikai intenció - az irodalom fennállásának veszélyeztetése nélkül - ezért maga is csak a kánoni elv premisszái szerint képes működésbe lépni.

A kánon alakulása körüli szövevényes recepciós mozgás leírhatóságát manapság persze nem csak az nehezíti, hogy az egykori (olykor erősen politikai töltetü) kánonkritikus potenciálból nem születtek új alapokra helyezkedő és szakmailag is hatékonyan artikulált vagy konszenzuális érvényű kánonértelmezések. Ezek hiánya alighanem azzal magyarázható, hogy az utolsó nagyszabású, Paul de Man-féle kánonkritikai program aporiáit (nyomukban a Barbara Herrnstein Smith ${ }^{7}$ és a Jan Gorak ${ }^{8}$ közti térben kialakult változatokkal) sem a kérdés Assmann-féle kulturális-emlékezeti kiterjesztése, sem a szakmailag szolidabb Winko-féle kísérletei nem tudták felülírni. Az irodalomnak ugyanis a csak az olvasás történéseiben „tetten érheto”" retoricitása az Allegories of Reading (1979) óta nem abban a szövegeket stabilizáló és elhatároló értelemben számít az irodalom „lényegének”, ahogyan azt az amerikai kánonvita legnagyobbrészt fenomenalizálta vagy „kategorizált” alakban alkalmazni próbálta. Igen jellemző, hogy Guillory - és még többen mások - például a presztízsüket vesztett irodalmi stúdiumok tárgyának új történeti meghatározásától várta az irodalmi autonómiájukban megőrzött szövegek és az őket „forgalmazó” diszkurzus összjátékának kulturális eredményességét.

A szövegek irodalmi autonómiájának kérdése ugyanakkor azért merülhetett föl ilyen bővített kontextuális összefüggésekben, mert a kánonkritikai szólamoknak úgyszólván közös a priorija volt annak előzetes(en felül sem vizsgált) vélelmezése, hogy a kanonikus értékkiválasztódás a „gyöngébbek”, az „elkülönböző idegenek” vagy a „szabálytalan és rendhagyó másságok” kirekesztésével jár együtt. A kánonértelmezésben már az 1980-as évektől fogva ezért is volt például magas presztízse annak a cenzúrafogalomnak, amely felől erős kritikai ellenfény vetülhetett a kanonizált művek történeti státuszára. Guillory nem véletlenül utalt egyebek közt arra, hogy az irodalmi kánonképződésben nélkülözhetetlen értékszelekció elvét hatalmi úton befolyásolhatónak beállítva számos amerikai egyetemi curriculum törekedett olyan politikai programok leplezett érvényesítésére, amelyek

KAsSÁK Lajos, $A$ „rettenetes nagy hamu alól” Babits Mihályhoz, Nyugat, 1916/18., 424. Az avantgárdnak ez az alapvetően még mindig produkcióesztétikai érvelése a maga következetlenségei ellenére is nyilvánvalóvá teszi annak szándékát, hogy - amint azt az „örökégő fáklya” formulája is hangsúlyozza - Kassák nem a megszakítottságban, hanem a folytonosságot fenntartó irányváltásban látja a díszítetlen „életdarabként” értett avantgárd vers kánoni lehetőségeit.

7 Barbara Herrnstein Smith, Contingencies of Value = Canons, szerk. Robert von Hallberg, Chicago UP, Chicago-London, 1984, 5-39.

8 Jan Gorak, Making of the Modern Canon. Genesis and Crisis of a Literary Idea, Athlone, London - Atlantic Highlands, 1991.

9 Lásd John Guillory, Cultural Capital. The Problem of Literary Canon Formation, Chicago UP, Chicago, $1993,262-265$. 
sikertelennek bizonyultak vagy kifejezetten megbuktak a nyílt politikai kompetíció elsődleges terében. ${ }^{10} \mathrm{~A}$ kánon megkerülhetetlenségét színre vivő kánonkritika paradoxonain túl az irodalmi kánonok viselkedésének feltárhatósága azonban továbbra is annak a recepciós kettősségnek áll a horizontjában, hogy bár a kánoni rangról - hatás, befogadás és utóélet összefüggésében - a mindenkori olvasók ítéletei döntenek, de azon esztétikai-poétikai minőségeknek a textuális, műfaj- és hatástörténeti viselkedését, amelyek az irodalmi hatás „kiváltói”, az akadémiai diskurzus hivatott feltárni, értékelni - s kánoni rangjukat ilyen módon szakmailag indokolni.

Ezt a diskurzust eredendően az irodalomtudomány egyes ágazatainak értelmezései tartják ugyan mozgásban, de értékítéleteik csak áttételes módon érik el azokat az intézményeket, fórumokat és médiumokat, amelyek - mint az oktatás, a kulturális piacok vagy a szocietás identitásalkotó stratégiái - közvetlenebbül befolyásolják a szélesebb olvasói nyilvánosságot. Mindenesetre azzal szemközt, hogy az „irodalmat olvasók” gyűjtőnév mint végső instancia - igen heterogén csoportokat, intézményeket és médiumokat foglalhat magában, a szaktudománynak ha nem is feladata valamely átfogó kulturális orientáció érvényesítése, az irodalmi értékek tartós autonómiájának szolgálatában folytonosan a kánoni képződés nyelvművészeti premisszái szerint kell elvégeznie a jelentésgondozás munkáját.

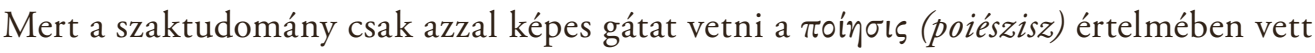
irodalomhasználati „átlényegítésének”, ha a klasszikusokon élősködő aktualizációkkal nem a kánoni művek „időtlenségét” szögezi szembe, hanem az alkotott létrehozottság ${ }^{11}$ történeti egyedisége felől világítja meg az esztétikai tapasztalatnak azokat a (kanonizációt is érintő) kérdéseit, amelyeket a maga közlési igénye szerint „minden műalkotás felvet és aztán az utána még lehetséges "megoldások" horizontjaként hagy hátra”. ${ }^{12}$ Mert végső soron ez a tetszőlegesen nem alakítható horizont az egyedüli, ahol a lezárhatatlan jelentésképződés elve megkülönböztethető a használatbavétel önkényétől.

Különös jelentősége van ennek éppen a kánoni helyzetű művek esetében, amelyek - mivel eleve is annak köszönhetik a kanonizáltságot, hogy olvasók történeti sorát képesek új esztétikai önmegértésben részesíteni - a szokásosnál jobban rá vannak utalva a jelentéskeletkezés ártatlanságának védelmére. Közismertségük okán ezek ugyanis fokozott mértékben vannak kitéve olyan, a szöveg közlési igényeit „elhajlító” vagy instrumentalizáló értelmezéseknek, amelyek - leggyakrabban a befogadás elvi „pluralizmusát” vagy a személyes olvasástapasztalat

10 Összefoglalólag lásd Uo., 3-37.

11 Olyan alkotó tevékenység eredménye, amely jelenlévővé tesz, „elénk állítva” hoz létre valamit, ami eladdig nem létezett. Ehhez lásd Martin Heidegger, Die Frage nach der Technik, Klett Cotta, Stuttgart, 2002 $2^{10}, 11$.

$12 » O p$ " "pop» oder die immer zu Ende gehende Geschichte der Kunst [Hans Blumenberg hozzászólása P. Beylin elöadásához] = Die nicht mehr schönen Künste. Grenzphänomene des Ästhetischen, szerk. Hans Robert JAuss, Fink, München, 1968, 692. (Poetik und Hermeneutik, 3.) 
szuverenitását hangoztatva - irodalmon kívüli programok esztétikai ideológiáit működtetve hatolnak be az irodalomba. Közelebbről is a műveknek abba az autonóm nyelvmüvészeti terébe, ahol a szöveg eredendően egyazon aktusban létesíti is azt, amiről beszél. Az így létesült „világok” nyelvi és fenomenális formájának szétválasztására irányuló törekvés a maga természete szerint mindig ideológiai ugyan, de különösen akkor veszélyezteti a közlés irodalmi igényét, amikor a müvek és formák „pusztán” poétikai hatástörténetét valamely magasabb rendü, az irodalmon mindig „túlmutató” humán küldetés és eszmekör történeti koordinátáinak megfeleltetve akarja - immár kánonképző igénnyel - értékelni. Ezek a kísérletek ugyanakkor Horváth Jánostól Szabolcsi Miklósig makacs kísérői a hazai irodalomtörténeti értékelésnek, holott szigorúan véve az anapesztus lüktetésének éppúgy nem tartozéka a hősi halál pátoszának dallamíve, ${ }^{13}$ mint ahogy az újklasszikus bukolikának sincs humán önvédelmi potenciálja. ${ }^{14}$

\section{A kánon „történése”}

Az irodalmi rendszer környezeteként működő kulturális ideológiai hálózatban a szaktudomány mindössze képviselni képes a szövegek poétikai autonómiáját, nem pedig érvényesíteni. Mielőtt azonban a kánon viselkedésének kérdéseibe bocsátkoznánk, érdemes tisztázni, hogy az irodalom hatástörténeti valósága egyszerre kiindulópontja két olyan külső „kánonhordozó” instanciának is, amelyek jelentős tartalmi érintkezés jegyében ugyan, de eltérő kánoni intenciók érvényesítésében érdekeltek. Az olvasóknak az a művelt, de nem professzionális, erős mediális támogatással tájékozódó rétege (s azon belül annak csoportjai), amelyet az úgynevezett müveltségi kánon hordozójának szokás nevezni, a nyelvközösségi kulturális identitás értékrendje szerinti kánonnak még akkor is a legszilárdabb „bázisa”, ha a kanonikus olvasmányokhoz való viszonyuk különbözik egymástól. Nem minden művelt olvasó tartja ugyan éppoly vitathatatlannak Petőfi vagy Jókai rangját, mint Kemény Zsigmondét vagy Arany Jánosét, miközben egyaránt „klasszikusként” tartja őket számon. De Móricz vagy Németh László hívei sem szokták megkérdőjelezni Babits vagy József Attila kánoni jelentőségét. Ez a különbözés itt nem olyan mértékü, hogy értékszemléleti premisszáik (elsősorban a magas irodalomhoz tartozás szempontjából) kizárnák egymást. Ugyanakkor: a magas irodalomhoz tartozás dolgában Ignotus novelláit még azok sem

13 „.... porhüvelyét tűzbe lobbantó lelki villámlás mennydörgése ez”. Horvátu János, Petőfi Sándor, Pallas, Budapest, 1922, 376.

14 „A magyar »újklasszikusok«, antikvitáskeresők, formafegyelmezettek egész magatartásának határozott német- és náciellenes éle volt, úgy érezték, a formával, a fegyelemmel, a megszenvedett szépséggel harcolnak a fasizmus ellen." Szabolcsi Miklós, Idöszerü-e a Radnóti-magatartás?, Irodalomtörténet, 1995/1., 86. 
helyeznék Kosztolányi elbeszélései elé, akik művészeti értéket látnak az irodalmi „progreszszióban”, vagy ízlésszerkezeti okokból idegenkednek a humánrelativizmus következtetéseitől. Sőt irodalmi értékesség tekintetében - olvasóik erősen eltérő kulturális tájékozódása ellenére - még a Nyugat és a Napkelet sem törekedett a magas irodalom örökölt esztétikai alapelveinek felülvizsgálatára. Lényegében ezzel biztosították a saját kánonjaik közötti érintkezést, sőt bizonyos fokig az átjárhatóságot is. ${ }^{15}$

A tájékozott és iskolázottabb olvasók müveltségi kánonjának azonban - még valamely tartós és egységes (?) korízlést feltételezve - sincs olyanfajta önmagából származtatható, immanens alakulásrendje, mint a művek (nyelvek és formák) belső hatástörténeti kánonjának. A műveltségi kánon ezért egyszerre van kitéve a közvetlenebb és gyorsabb közvetítésü külső körülmények hatásainak, illetve az oktatás és művelés intézményi interpretációin „átszürt” és reflektált akadémiai kánonok befolyásának. Emiatt szorulnak irodalmon túli magyarázatra olyan jelenségek, mint Herczeg Ferenc ${ }^{16}$ vagy Zilahy Lajos - nyelvművészeti szempontokkal kielégítően alá nem támasztható - olvasmányirodalmi népszerüségének keletkezése, viszonylagos tartóssága s az elnémítást követő „újraéleszthetetlensége”. Műveltségi és akadémiai kánon viszonyának szövevényességét szemléltetheti másfelől, hogy két olyan, egyaránt 1942-ben keletkezett mü is a külföldi sikert követően vált itthon népszerüvé, melyek egyike a megalkotottság egyenetlensége, másika pedig az esztétikai tapasztalat sematikus kalkulálhatósága okán nem tett szert akadémiai kánoni rangra (Füst Milán: A feleségem története, Márai Sándor: A gyertyák csonkig égnek). A műveltségi kánonnak tehát az a különös paradoxona, hogy míg egyfelől róla olvashatók le a legmegbízhatóbban az iskolázott olvasási kultúra tartósabb ízlésalapzatának jellemzői, ez utóbbiak csak csekély mértékben „képezik le” a hatástörténeti kánon kiemelkedő értékformáit. Jóllehet, ez a kánon Kazinczy - de legalábbis Toldy Ferenc - óta sokkal tartósabbnak/stabilabbnak bizonyult, mint ahány változáson az ízlés kulturális alapzatának története keresztülment. Ami annak az eddiginél komolyabb megfontolására is késztethet, vajon szakmailag tényleg olyan biztonságos talajon mozog-e az a vélekedés, mely szerint az irodalmi értékkeletkezés mindig megfeleltethető a kulturális környezet alakulásának.

A műveltségi kánon és a szakmai kánon közötti feszültségek azonban lényegesen tompulnak a 19. század előtti szövegek világában. Ennek nemcsak abban van az oka, hogy a 17-18. századi szövegek befogadását kevésbé terhelik identitásképző, legitimációs vagy

15 Sőt, visszatekintve Schöpflin azt állapítja meg, hogy „a Napkeletben érvényesült irodalmi szempontok lényegileg nem különböztek a Nyugat szempontjaitól, amelyek már a Napkelet kezdetekor, évek súlyos polémiái révén általában a komoly irodalmi közvélemény szempontjai voltak." ScHöpflin Aladár, Búcsú a Napkelettöl, Nyugat, 1940/10., 478. (Kiemelés - K. Sz. E.)

16 Akit Szinnyei Ferenc már a húszas években az akadémiai kánonba emelve jellemzett az akkori „magyar szépirodalom legtekintélyesebb személyisége[ként]". Ludwig Katona - Franz Szinnyei, Geschichte der ungarischen Literatur, Walter de Gruyter, Berlin-Leipzig, 1927², 158. 
kultúrorientációs igények, hanem abban is, hogy az ezredvég olvasási horizontján az esztétikai tapasztalat szerkezetváltozásai az iskolázott olvasórétegeknél is csupán technéként képesek előhívni a klasszicizmus irodalmi önmegértésének örökségét. És valóban, Weöres, Kovács András Ferenc vagy Esterházy néhány népszerű (ám a korszakos távolságok elidegenítő hatását fölszámolni képtelen) intertextusától eltekintve az utómodernség irodalmának legföljebb a 19. század második felével zavartalan a nyelvi kapcsolata. Az utóbbi két-három évtized irodalmának nyelvi valóságát már Vörösmarty lírájához sem kötik olyan hatástörténeti kapcsolatok, mint amilyenek szerkezet, hangoltság és dimenzionalitás tekintetében Pilinszky vagy Juhász Ferenc - kivált pedig Babits Mihály - képalkotásmódját jellemezték. Azt mondhatnánk, az esztétikai megkülönböztetés tanának mai, még mindig a képi metaforika és a nyelvjáték élvezetértékeiben megalapozott befogadásmódja a művelt olvasás egyik változatában sem ismer már magára Berzsenyi vagy Kazinczy nyelvi világában. A Petőfire már csak nyomokban emlékeztető képviseleti költészet Csoórinál is inkább a lírai alany drámáját, mintsem a képviseltekét írta, ahogyan Illyés lírája is csak ritkán tudta töretlenül színre vinni a maga „küldetettségének” megbízási eredetét. ${ }^{17}$ Akárhogy van is, több kérdezési irányból valószínűsíthető, hogy a művelt-olvasói kánon körébe tartozó olvasmányok tényleges tartománya mára már nemigen terjed túl a (még „olvasható”) 18. századi szövegeken. Sőt, itt még Kazinczy rendszeres olvasása sem vélelmezhető, egy kritikailag újraalapozott Gyöngyösi- vagy Mikes-kiadás pedig már aligha volna több - Schlaffer analógiájával élve - valamiféle filológiai újratemetésnél, egyik díszsírhelyből a másikba.

Ezzel a történetileg rövid távú kánonnal szemben a szisztematikus akadémiai kánont maga az az irodalomtudomány képviseli, amelynek azért kitüntetettek a lehetőségei (és a feladatai), mert vizsgálódásait arra kell összpontosítania, hogy a szövegek poétikai hatástörténete miként és mikor értékel föl műveket és eljárásokat, illetve hogy miért helyez háttérbe korábban beszédes alkotásokat. Mindezt viszont annak tudatában kell végeznie, hogy az irodalmon kívüli térben ez a belső hatástörténet maga képtelen bármit is kanonizálni. Ennyiben, de csak ennyiben igaza van az újabb kánonszakirodalomnak, amikor ismételten kategorikusan leszögezi, hogy „a kánont csinálják”. ${ }^{18}$ Az irodalomtörténeti kánonképződés folyamatában tehát ugyan egyedül a belső hatástörténetnek van irodalmi érvénye, de az erre a bázisra építkező intézményi kánonalkotás sokkal összetettebb folyamat annál, hogysem kijelenthetnénk: a nyelvművészeti értékek szisztematikus (az akadémiai kánontól el nem szakadó)

17 Halász Gábor már 1929-ben csalhatatlan költészettörténeti érzékkel figyelte meg, hogy „[a]z úgynevezett kollektív lírának sincs semmi köze a kollektivitáshoz (amely különben teljesen határozatlan fogalom), benne is csak az én ágaskodik nevetségesen és tehetetlenül, szárnyaszegetten próbálgatva a régi repülést. Az új egyszerűség és népiesség nálunk feltűnő verselői meg-megüthetnek egy húrt a lelkünkben; a líra sorsában alig van szerepük." HaLÁsz Gábor, A líra halála, Napkelet, 1929/11., 835-836.

18 Simone WINKo, Literatur-Kanon als invisible hand-Phänomen, TEXT+KRITIK Sonderband, 2002, 9. 
közvetítésének letéteményese egy olyan oktatási szisztéma volna, amelynek a műveltségi és szakmai kánon közti átjárhatóság biztosításában állna az egyensúlyteremtő feladata. Nem utolsósorban az általános-közösségi vezérlő értékek szerinti kulturális orientációt szolgálva. Általánosan véve alighanem egy - a nyelvművészeti értésmódot korlátozó - emancipatorikus, egalitarista vagy célzottan szociális töltetű irodalomeszmény túlélésével magyarázható, hogy az oktatásban Thomas Mann kánoni helye nálunk hat évtizede éppoly megingathatatlan egy Hamsunnal vagy Musillal szemben, mint a Barbároké a Valér a földbe megy vagy az Öszi éjszaka ellenében. Ez utóbbi már csak azért is kevésbé magyarázható, mert sem Tömörkény, sem Petelei szövege nincs híján szociális vonatkoztathatóságnak. Sőt narratív drámaiság és az elbeszélés különleges érzékleti kódoltsága tekintetében három évtizeddel előbb létesítik egy olyan, naturalizmuson túli modern novellisztika alapformáit, amelynek nyelvi-poétikai alakzataihoz jóval összetettebb hatásszerkezet tartozik, mint amilyenre a kezdetleges animalizáció Móricz megkésett művében alkalmas. ${ }^{19}$

Miközben tehát igaz, hogy a modernségtől távolodva - a kisebb széthangzások ellenére - inkább összhang és megfelelés jellemzi a mủveltségi és az akadémiai kánon viszonyát, a kortárs kánonképződés ritkán mutat egybehangzást közöttük. Nemcsak azért, mert az élő kapcsolat miatt az irodalmi közelmúlt nem adhat tovább olyan stabil és rendezett kánoni örökséget, amely a maga nehézkedésének ellenerejével problematizálhatná az akadémiai kánon értékrendjét. Azért is, mert a tapasztalat szerint ezzel a még mozgásban lévő örökséggel szemközt magában az akadémiai kánonban is erősebbek a széthangzások, mint amelyek a távolabbi korok kutatásának következtetéseiből adódnak. Az a viszonylag tágas műveleti tér ráadásul, amely a stabilitás kölcsönös hiányában a műveltségi és a szakmai kánonképződés között felnyílik, éppen nem az utóbbinak kedvez, hiszen a mindenkori műbírálat diszkurzív praktikái a műveltségi kánont próbálják befolyásolni. Ennyiben biztonsággal kijelenthető, hogy a jelent tudomásul nem vevő irodalomtudomány mindig elvéti ugyan az irodalmi össztörténés valóságát, de azzal még, hogy a hatástörténet aktuális végpontján szaktudományi eszközökkel értelmez kortárs teljesítményeket, nem lesz egyedüli vagy kitüntetett letéteményese a kanonizációnak. Mivel a kánonképződés értékformák és intenciók szerinti összetettsége következtében a mindenkori textuális-esztétikai értelmezéshez társuló, „motivacionális” ${ }^{20}$ értékek együttese éppúgy kánont befolyásoló tényezővé válhat, mint a kulturális identitásképző stratégiákhoz tartozó legitimációs és orientáló

19 A Budapesti Szemlében Péterfy már közvetlenül a Le Roman expérimental (1880) megjelenése idején figyelmeztetett a homo animal „körmönfont doctriná”-jára (PÉTERFy Jenő, Jókai Mór, Budapesti Szemle, 1881/52., 2.) és a naturalizmus jegyzőkönyvi „hitelességének” megtévesztő művészietlenségére. (Lásd Uö., Le roman expérimental, Budapesti Szemle, 1882/69., 312-319.)

20 Winko kifejezése olyan értékformák jelölésére, amelyek „a cselekvés vagy a magatartás tudatos vagy öntudatlan motiválói” lehetnek. Simone Winko, Wertungen und Werte in Texten, Vieweg, Braunschweig, 1991, 37. 
funkciók, az irodalomtudomány feladata nagyjából arra korlátozódhat, amire a szakterületi illetékessége kiterjed. Mert bár a kánonképződés nem elsődleges (s főként nem tisztán) irodalomtudományi kérdés, ennek az illetékességnek elválaszthatatlan kanonizációs implikációi vannak. Legalábbis amennyiben kánon nélkül éppúgy nem lehetséges irodalom, mint szövegek nélküli kanonitás. Ennyiben az irodalomtudománynak arra irányulhat a kánonvonatkozású érdekeltsége, hogy közremüködjék annak feltárásában, nyelvmüvészeti szempontból „mi érdemelné meg, hogy újra meg újra (el)olvassák”. ${ }^{21}$

Márpedig ha az irodalom értelmére vonatkozó kérdés szükségszerűen a befogadásnál végződik, annak feltárhatósága, hogy egy nyelvi és kulturális közösség körében mi számít irodalomnak, okvetlenül kánoni státuszú szövegek (meg)létéhez van kötve. A fentebbi összefüggések bizonyos kényszerű átfordításával itt úgy is fogalmazhatnánk: a kánonban ugyan mindig leképződnek a jelentésképzés esztétikai ideológiái, de annak a poétikai hatáspotenciálnak a működését, amely nyelvművészeti tapasztalatként konstituálja az olvasásra érdemes szövegek igazságának történéseit, csak a szaktudomány képes az irodalmi művek és formák belső hatástörténeteként megjeleníteni. Ez a belsö, szakmai hatástörténeti interpretáció ugyanis - miközben maga is tényleges recepciós történések közegében mozog - nem annak alakulását ellenőrzi, hogy az adott szövegösszefüggések alapján a befogadásnak milyen értelemegészre kell törekednie, hanem azt követi figyelemmel, hogy a költői nyelvek és formák élő hatástörténeti dialógusában mi történik az olvasással. E műveletek során nemcsak arra derül fény, hogy a primer irodalmi értékképződés miért nélkülözhetetlen alapzata egy-egy nyelvi közösség műveltségi kánontudatának, hanem arra is, hogy az esztétikai önmegértés milyen jóvátehetetlen - mert korszakos, episztémétörténeti mértékü - zavarai keletkezhetnek olyan körülményekből, amikor a kánonképzés folyamata valamely okból preferált vagy akár előre eldöntött, rögzített kulturális értékösszefüggések vezérlése alá kerül. ${ }^{22}$ És bár az ilyen fejleményeknek legfeljebb a megállapítása, nem a magyarázata tartozik a feladatkörébe, az irodalmi olvasás kimeríthetetlen kihívásait jelentő alkotások poétikai-hatástörténeti értelmezésének konszenzuális szükséglete még akkor is a szaktudományt teszi a kánonképződés végső hivatkozáspontjává, ha a kánont hordozó intézményi diskurzusra a tudománynak csupán áttételes módon van befolyása.

21 Friedrich Nietzsche, Kritische Studienausgabe, II., DTV, München, 1999, 599.

22 Nálunk különösen az kuszálja össze ilyenkor a művelt nyilvánosság ilyen jellegű befolyásolásának egyébként jól követhető alakulását, hogy a preferált diszkurzív pozíciók (gender, kisebbség, regionalitás stb.) olyan sérelmi interpretációs modellek hálózatában jelennek meg, amelyekben a különféle eredetű ,jóvátételi” intenciók hol igenelni, hol tagadni kényszerülnek az itt jelentkező - és az irodalomtól már igen messze távoldott - legitimációs igények fajtáit. Annak eközben alig marad irodalomesztétikai relevanciája, hogy kereskedelmi-mediális jelenlét dolgában Szilágyi István vagy Bodor Ádám prózájának „régiótapasztalata” miért marad a Dragomán-könyvek árnyékában, vagy miként kerül Balla Zsófia költészete ilyen „magától értetődően” például a Ladik Kataliné elé. 
A kánon indoklásának konszenzuális szükséglete ugyanakkor azért számít ebben az összefüggésben nélkülözhetetlennek, mert a szép(ség)et „érvénybe lépteto”” esztétikai ízlésítélet a kanti értelemben mindig helyeslésre tart igényt, azaz „a megerősítést nem fogalmaktól, hanem mások csatlakozásától várja”. ${ }^{23} \mathrm{~A}$ (mindig szubjektív) esztétikai ítélőerő képessége ugyanis olyan közös érzéket feltételező tetszésre támaszkodik, „amelyet anélkül teszünk egyúttal szabállyá mindenki számra, hogy az ítélet érdeken alapulna vagy érdeket hozna létre”. ${ }^{24} \mathrm{~A}$ kánonképzés e megkerülhetetlen feltétele miatt még az a kánonképző akarat is az esztétikai értéktapasztalat megosztható érvényéből szokott kiindulni, amelyik irodalomtörténeti áldozatoknak tekintett szerzőkre, illetve a műveik megtestesítette ellenkánonokra bízza saját esztétikai ideológiáinak irodalmi képviseletét.

Bár a kánonképződés - a benne közreműködő kulturális és szociális tényezők sokasága okán - a maga komplexitásában szinte formalizálhatatlan folyamat, hosszabb távon abban is a szaktudományi értékelés orientáló érvénye mutatkozik meg, ahogyan a megszilárdult státuszú klasszikusok (Balassi, Zrínyi, Vörösmarty, Petőfi, Arany, Madách, Kemény, Jókai, Ady, Babits, Kosztolányi, József Attila, Pilinszky) körül még mindig olyan szerzők (Gyöngyösi, Berzsenyi, Kazinczy, Katona, Mikszáth, Krúdy, Móricz) és művek együttese alkotja a következő kört, amelyeknél az előbbiekhez képest csupán az egyöntetủ esztétikai elismertség mértéke mondható csekélyebbnek. A kánon peremére inkább azok a kiemelkedő szerzők (Kassák, Szabó Lőrinc, Illyés, Ottlik) és alkotások szorulnak, amelyeknél még fennáll az esztétikai megítélés változékonysága. Beszédes ebből a szempontból az is, hogy a régebbi magyar irodalomtörténet kánonja lényegében továbbra is Toldy Ferenc szaktudományi munkáin nyugszik. Ezen a kánonon vagy inkább annak képződési logikáján egyelőre kevésbé hagyott nyomot annak törvényszerűsége, hogy a kánont leginkább saját - a művek mindenkori megszólítóerejétől független megszilárdulásának tartóssága fenyegeti.

Mindenesetre annyi különösebb szakmai kockázat nélkül állítható, hogy a kánont olyan össztörténés állítja elö, amelynek a fölérendelt, azaz a történést „vezérlő” szubjektuma megnevezhetetlen. Ez a konfiguratív történés olyan sokfajta tényező összjátékán keresztül megy végbe, hogy ezek dinamikus és nem modellezhető viszonya - irodalomtudományi eszközökkel legalábbis - hozzáférhetetlen. A kánon létmódjának alighanem szintén ugyanazért nehéz a meghatározása, mert tartós fennállását nem csupán a folyamatos hatástörténeti keletkezés és múlás biztosítja, hanem irodalmon kívüli erők szerteágazó érdekeltségei is közreműködnek az alakításában. Nagyszámú fórum, intézmény, médium és közösség tartja ugyanis illetékesnek magát abban, hogy e diszpozitívumként ${ }^{25}$ működő hálózat terében mi

23 Immanuel Kant, Az itélöerö kritikája, ford. PApp Zoltán, Ictus, Budapest, 1997, 131.

24 Uo., 225.

25 Foucault értelmében a diszpozitívum ama szimbolikus helynek tekinthető, ahol a tudás és műveltség 
lépjen érvénybe az irodalmi olvasmányok kánona gyanánt. Miközben tehát az irodalmi kánont az össztörténés szubjektuma (illetve e történések nem formalizálható és stabilizálhatatlan, mégis mindig működő szabályrendszere) úgy, olyan alanyként tartja mozgásban, mint a játék a játszókat, ez a történés folyamatosan annak paradoxonát erősíti meg, hogy bár kánon nélkül nem lehetséges irodalom, a kánon kérdése mindig átlépi a művek, nyelvek és formák „összjátékának” tisztán irodalmi határait. Ha tehát az állítás logikailag nem veszélyeztetné önmagát, úgy is fogalmazhatnánk, a(z irodalmi) kánonképződés valójában nem a szorosabban vett irodalomtudomány problémája.

Mindezzel szemközt a kánonértelmezés azzal sem szabadulhat a maga legsúlyosabb dilemmáitól, ha ama jól ismert kérdésre egyszerűsíti a kánonképződést, hogy valamely szerző vagy műalkotás vajon önmaga erejéből, esztétikai minőségeinek köszönhetően tesz-e szert kánoni rangra, vagy pedig a recepciós erők autoritatív döntése tartja őt a felszínen. Az így feltett kérdés horizontjában ugyanis nem feltétlenül valamely intézményi autoritás beavatkozása kelt feszültséget a két nagyobb kánoni terület között, hanem a poétikai hatástörténet erővonalainak belső átrendeződéséből adódó következmények. A műveltségi kánonban Musil vagy Broch például annak ellenére sem közelíti meg Thomas Mann helyét, hogy elbeszélő művészetük jóval jelentősebb hatást gyakorolt a modern prózaírásra, mint pályatársuké. És Mallarmé lírájának köszönhetően is hiába ment végbe - ehhez képest több évtizeddel korábban - Nerval költészettörténeti felértékelődése, a műveltségi kánonban máig nem olyan szilárd a helye, mint az úgynevezett nagy romantikusoké (Hugo, de Vigny). Az intézményi beavatkozás hosszabb távú sikertelenségének másfelől pedig az lehet jó példája, hogy a műveltségi kánonból a nálunk hivatalosan még az 1970 es években is szorgalmazott közéleti irodalomeszmény sem tudta kiszorítani a klasszikus modernség nagy kisugárzású esztétikai örökségét. Aligha függetlenül attól, hogy a primer költészettörténeti folyamatokat jóval hatékonyabban alakították Pilinszky és Nemes Nagy költői nyelvének retorikai mintái, mint Nagy László vallomásos alapkarakterủ vagy Juhász Ferenc látványelvű, szómágia működtette költészete.

- hatalmi technikákkal összekapcsolódó - elólllítása végbemegy. „Az, amit ezzel a fogalommal jelölni próbálok, az először is egy diskurzusokból, intézményekből, építészeti létesítményekből, szabályozó döntésekből, törvényekből, adminisztratív intézkedésekből, tudományos kijelentésekből, filozófiai, morális és filantropikus/emberbarát tételekből, röviden, mondottakból és nem mondottakból álló, határozottan heterogén összesség. Ezek a diszpozitívum elemei. A diszpozitívum maga az a háló(zat), amelyet ezek közt az elemek közt előállíthatunk. Másodszor az, amit a diszpozitívum fogalmában rögzíteni szeretnék, az éppen annak a kapcsolatnak a természete, amely e heterogén elemek között fennállhat." Das Spiel des Michel Foucault = Michel Foucault, Schriften in vier Bänden, III., 1976-1979, ford. Michael Bischoff és mások, Suhrkamp, Frankfurt am Main, 2003, 392. 


\section{Az önmagát alkotó kánon láthatatlansága a kortárs irodalomban}

A mindenkori jelen elvileg nem rendelkezhet a művek és formák hatástörténetére támaszkodó, abból megbízhatóan „levezethető” kortársi kánonnal. Éspedig több okból sem. Ezek némelyikét a következőképpen foglalta össze az egyik nemrég komolyabb „kánonvitát” kiváltó irodalomtörténet szerzője: „Éppenséggel arról az időről a legnehezebb ítélni, amelyhez magunk is hozzátartozunk. Kortársként a történész nem rendelkezik megbízhatóbb tudással, mint a kritikus vagy az olvasók akármelyike. Mindannyian a korszak elöítéleteinek foglyai. A kánonképződés története legalább egy dologra megtanít bennünket [...]. [Nevezetesen, hogy] a kortársak közül még a legképzettebbek sem a megfelelő könyveket (die richtigen Bücher) olvasták és ezeket sem olvasták megfelelően. Az irodalom kanonizációja általában harminc vagy ötven évvel a megjelenése után kezdődik.” ${ }^{26}$ A kánonképződés fentebb jellemzett soktényezős mozgásából adódóan ugyanakkor értelmetlen tagadni, hogy a jelenben mégiscsak vannak kánonok. Az alternatív vagy párhuzamos kánonok azonban a legátfogóbb értelemben különféle rendü-rangú irodalmi/kulturális, sőt politikai ideológiák termékei, s annyiban mindig az irodalmat instrumentalizáló érdekeltségek megtestesítői, amennyiben könyvek, művek és szerzők kánoni rangra emelésével törekednek - különféle küldetéstudatok jegyében - egy szélesebb kulturális nyilvánosság befolyásolására. Ezek a szó szoros értelmében véve nem az irodalmat transzcendálják, hanem ellenkezőleg, a poétikai partitúrát megbontó intervenciókkal olvasnak rá olyasvalamit a szövegekre, amelyről azok - saját közlésigényük szerint legalábbis - nem szólnak. Itt tudniillik a kánonképzés legrejtettebb művelete lép működésbe: a műalkotás - a maga szövegpartitúrájáról úgyszólván leválasztva elsődlegesen nem mint megalkotott szövegmü válik hivatkozási ponttá, hanem olyan esztétikai-kulturális autoritásként, ahol a szöveg valósága az üzenetnek rangot kölcsönző eszmék és értékformák foglalata csupán. Így tekintve - költözzék az bármely kulturális díszletek közé - a jelenkori kánonok kérdése minden egyéb, csak nem irodalomtudományi probléma. Mert az bár igaz, hogy a kánon mindig olyasvalami, amit egy soktényezős össztörténés „állít elő”, de a hordozója, nélkülözhetetlen forrása mindig az egyes irodalmi műalkotás, amely nélkül nincs mit kanonizálni. Kánon nélkül éppúgy nem lehetséges irodalom, mint szövegek nélküli kanonitás. Ugyanakkor „egy irodalmi mű minősége és rangja nem a keletkezésének biográfiai vagy történeti feltételeiből s nem is kizárólag a műfajfejlődés sorrendjében elfoglalt helyéből adódik, hanem a hatás, befogadás és utóélet nehezebben megfogható ismérveiből”. ${ }^{27}$ A hatás, a befogadás és az utóélet itt

26 Heinz Schlaffer, Die kurze Geschichte der deutschen Literatur, Anaconda, Köln, $2013^{2}$ [2002], 133. 27 Hans Robert Jauss, Literaturgeschichte als Provokation, Suhrkamp, Frankfurt am Main, 1979, 147. 
olyan meghatározó faktorok, amelyeknek a temporalitása kizárja az előidejüséget, azaz: mindenkor kalkulálhatatlanná és tervezhetetlenné teszi bármely kortársi mű tényleges, irodalmi kanonizálódásának bekövetkezését.

A jelenkori kánon kérdése ráadásul nehezen értelmezhető anélkül a szintén nem irodalmi körülmény nélkül, amit átfogó értelemben a csereforgalmi térbe beíródott, nyereségtermelő rendelkezésre állás és az árulét diszpozitívuma jelent. Ebben a rendszerben a könyvfesztiválok szezonális kánonjainak vagy a kereskedelmi bestsellerlistáknak éppúgy nincs komolyabb utóélete, ahogyan az előtérben tartott tematikák irodalmi ágensei is - mondjuk Ulickajától Ferrantéig - csupán a kínálati frissítés cserélhető eszközeinek számítanak. Ez az akadémiai és a magas műveltségi kánon köré épülő nyereségorientált kereskedelmi hálózat azonban - noha ajánlatai nagyon megtévesztők lehetnek még a müvelt olvasói réteg számára is - a mindig megújítandó kínálatával tartósan nem hat vissza egyik kánoni mezőnyre sem.

Ugyanakkor, ha úgy tekintjük, hogy a jelen bizonyos értelemben még mindig utótörténete a nagy, a maga nyitottságában a századelőn osztatlannak ígérkező modernségnek, akkor azzal is számolnunk kell, hogy a kánonképződésnek poétikailag a romantikához képest is összetettebbek és divergens erővonalaktól tagoltak a hagyományai. Mert az igaz ugyan, hogy a klasszikus modernség az innovatív esztétikai (nem pedig társadalomkritikai) eredetiség programja jegyében integrálta a maga fóbb századfordulós irányait, de még a tízes éveket sem kell elérnünk ahhoz, hogy a kánoni hagyományképződés olyan széttartó impulzusok terepén találja magát, amelyeknek úgyszólván alig vannak poétikai érintkezési pontjaik. Hagyományos kifejezéssel a stílpluralizmus korának nevezték ezt az 1970-es években (Žmegač $)^{28}$, de azok a távolságok, amelyek mondjuk a Germinal (1885), a Sult (1890) vagy az Algabal (1892), illetve nálunk később a Sárarany (1911), A vörös postakocsi (1913) vagy az Esti kérdés (1909) nyelvművészeti világai közt húzódnak, sokkal eltérőbb művészetszemléleti és poetológiai premisszákra mennek vissza, hogysem ma már csupán stíluskülönbségek gyanánt könyvelhetnénk el őket. Ez a divergens kibontakozás azon túl, hogy közvetve a kánonképződés összetettebb feltételeire is visszamutat, színre viszi a modernség egymást (le)váltó irányainak felgyorsult ritmusát is. Éspedig úgy, hogy egyszersmind felszínre hozza a korszakküszöbök kialakulásának nem tisztán irányzati tartalmait és karakterét is. Különös tekintettel arra, hogy a korszak- vagy periódusváltásoknak ekkorra már nemcsak a 17-19. századból ismert tempója változik meg, hanem az időszerkezete is: a feltorlódó irányzatok - időbeli értelemben már nem képezve tartós „lényegtartományt” inkább laterális struktúrákba rendeződnek, hatástörténeti viszonyaikat keresztirányú

28 Naturalizmus, szimbolizmus, szecesszió, impresszionizmus stb. Lásd erről Viktor ŽMEGAč, Zum literarischen Begriff der Jahrhundertwende (um 1900) = Deutsche Literatur der Jahrhundertwende, szerk. Viktor ŽMEGAČ, Athenäum-Hain-Scriptor-Hanstein, Königstein, 1981, IX-X. 
mozgások is jellemzik, és így részint „felülírják” az áramlatok lineáris keletkezési „rendjét”, az egymásutániság korszakképző logikáját is. Itt, ebben az összefüggésben látszik igazán, hogy miért idézi Móricz vagy Ady inkább már a nyelvszemléleti és poétikai félmúltat (E. és J. Goncourt: Germinie Lacerteux; E. A. Poe: The Haunted Palace, The Raven), holott a kánoni helyük eközben - kétségkívül nem tisztán irodalmi okokból - egy évszázadon keresztül stabilabbnak bizonyult, mint a Babitsé vagy a Kosztolányié, kivált pedig az alig később indult Kassáké.

A felgyorsult irányzati mozgás következtében olykor azonban nem csak az irodalmi hatástörténet fordulatainak kereshetjük hiába a nyomait a műveltségi kánon alakulásán. Váratlanul az akadémiai kánon új fejleményeit is ellensúlyozhatják olyan „korrektív” impulzusok, amelyekkel e fejlemények pillanatában nem számolhatott az akadémiai kánon aktuális tapasztalata. A létösszegző líra és az önmegszólító verstípus koncentrált kánoni elgondolása jegyében például bármily nagy - sőt szemléletalakító - jelentőségű volt is az 1970-es, 1980-as évek fordulóján Németh G. Béla versértelmezéseinek gyüjteménye, ${ }^{29}$ az ott (Ady feltűnő hiányával) kanonizált művek megszólító ereje számottevő változáson ment át már az ezredforduló idejére is. Ez a fejlemény értelemszerüen semmit nem von le Németh G. Béla munkájának implicit kánoni jelentőségéből, hiszen épp annak a Péterfy, Babits, Schöpflin és Halász Gábor képviselte hagyománynak a jegyében áll, amely a legnagyobb ellenerőt fejtette ki az instrumentalizáló kánonalkotással szemben. Mindazonáltal az élő költészettörténet visszaható horizontjában ehhez képest például nemcsak a Komjáthy-vers jelentősége halványult el feltűnően, de a szakmai kánonban a Balázsolás, $A z$ a szép régi asszony vagy $A$ Dunánál helyét is más nagy Babits- vagy József Attila-versek látszanak „elfoglalni”. Újólag alátámasztva azt a megfigyelést, hogy a kánoni egyöntetűség megingása a modernség időszerkezetének következménye, ami értelemszerüen tovább erősíti az alternatív jellegü kánonok fennállásának lehetőségeit is. Hogy az éleslátás és vakfoltok milyen kalkulálhatatlan összjátékán keresztül vezetnek még a szakmai kanonizáció útjai is, érdemes emlékeztetnünk rá, hogy - a Nyugat kánonát megalapítva - Schöpflin úgy előlegezi meg már 1937-ben a Komjáthy-líra elnémulását, ${ }^{30}$ hogy közben a „világirodalmi” eredetiségű (!) Móricz ${ }^{31}$ árnyékában tizennyolc sornyi

29 Németr G. Béla, 11 vers, Tankönyvkiadó, Budapest, 1977.; illetve Uő., 11+7 vers, Tankönyvkiadó, Budapest, 1984 .

30 „Ez a költészet szükségszerűen elhangzott s a feltámasztására való kísérletek a mostani század elején nem vezettek komoly eredményre." Schöpflin Aladár, A magyar irodalom története a XX. században, Grill Károly, Budapest, 1937, 39.

31 „A parasztember sorsának, küzdelmeinek, keserűségeinek és csalódásainak, szerelmi és házaséletének s mindezekből előállott világképének ehhez fogható ábrázolása nincs az egész világirodalomban" - írja A boldog emberről. Uo., 232. 
helyet biztosít József Attilának Fenyő László, Nadányi és Marconnay Tibor között. ${ }^{32}$ Halász Gábor pedig ugyanebben az évben - részben csak Petelei kivételével - nyilvánítja középszerűnek a századvég kísérletezőit. ${ }^{33}$

Az akadémiai kánon terén belüli mozgás - mint láttuk - eredendően a művek, nyelvek és formák hatástörténeti dialógusából, illetve értelmezhetőségük mindenkori lezárhatatlanságából, rivális olvasataik versengéséből nyeri a dinamikáját, ahol azonban még az „antikanonikus" olvashatóság is magának a szövegnek a mindenkori és elidegeníthetetlen tartozéka. ${ }^{34}$ Nem tartozik azonban a szorosabban irodalmi érdekü térbe a rajta túl működő, de róla csak nagyon precíz megkülönböztetésekkel leválasztható és igen összetett szerveződésű diskurzus, amely a kritikai praxis, az elektronikus és a nyomtatott sajtó, az irodalmi-kulturális társaságok és intézmények, a forgalmazás és ügynökségek hálózatán keresztül hat vissza a kánon már nem tisztán irodalmi megjelenésformájára. Az önmaga kimerülését és megújhodását is megtapasztaló modernség értékirányzati sokszínűségével szemközt az úgynevezett irodalmi életnek ez az üzemszerủ müködése a kulturális nyilvánosságban így meglehetősen viszonylagossá (vagy legalábbis nehezen érzékelhetővé) is teszi a szakmai és a műveltségi kánon választóvonalait. Tovább nehezíti itt a jelenbeli tájékozódást annak ténye, hogy a textuális tömegtermelés mai méretei mellett olyan áttekinthetetlenné duzzadt az átlagos/elfogadható művek irodalmi mezőnye, hogy sok tekintetben véletlenszerüvé is vált a médiumökonómiai hálózat uralma alá került értékformák irodalmi kiválasztódása.

Mármost ha az irodalmi élet ágenseit - többek közt az értékorientálás szelekciós kényszere okán - annak ellenére is erős kánonalkotó ambíció jellemzi, hogy az irodalom belső „kánoni” hatástörténete az egyidejüség jegyében nem befolyásolható, annak az lehet a magyarázata, hogy a kanonizálhatatlan kortárs irodalom recepciója erősen kötődik olyan relacionális értékeszmékhez, érdekformákhoz és motivacionális tényezőkhöz, amelyek az elrendeződött kanonitás helyzetében nem szoktak érvényesülni. Ilyenkor mindig fölmerül a kérdés, a modern kánoni örökség irodalomszemléleti optimalizációjának ideológiái vajon nem abban közösek-e mindenekelött, hogy egymásra utalva, nem kis anakronizmussal öntudatlanul is a művészeti korszak végének 19. századi ütközetét kényszerülnek újrajátszani. A mi irodalmi nyilvánosságunkban ott feszülő és rendre felszínre is törő feszültségek

32 Lásd Uo., 282.

33 Vö. Halász Gábor, Magyar századvég. Középszerü irodalom: a kisérletezők, Nyugat, 1937/11., 306-308.

34 A különböző, sőt - Bahtyin és Barthes vagy Benveniste és Petőfi S. János közt - polarizálható szövegszemiotikai pozíciókkal szemközt itt érdemes arra is emlékeztetni, hogy egy szöveg egyáltalán csak akkor számít szövegnek, ha - mint bizonyos fokú koherencia és egészjellegűség jegyében „megszövődő” struktúra - hozzáférhetőnek bizonyul az olvasás számára. A strukturáltság felismerhető nyomai híján a töredékesség valójában nem képes szöveggé válni. Ahhoz, hogy beszélni tudjon, „[a] szövegnek olvashatónak kell lennie.” Hans-Georg Gadamer, Szöveg és interpretáció, ford. Hévizi Ottó = Szöveg és interpretáció, szerk. Bacsó Béla, Cserépfalvi, Budapest, 1991, 25. 
terében annak irodalomidegen képletét képviselve, hogy a nagy magyar modernség - Adytól Petri Györgyig - a progresszió irodalmának, vagy hogy ugyanez az irodalom - Móricztól Csoóri Sándorig - a nemzeti géniusznak a megtestesülése volna. Mert ha jól megfigyeljük, az irodalom emancipatorikus-egalitarista, illetve sorsközösségi-népszellemi instrumentalizációja mintha a már-nem-szép-művészetek korának premisszáit fogalmazná újra - egy olyan technomediális környezetben, ahol időközben az is kérdésessé vált, létezik-e úgy az a küldetéses sors, ahogyan annak drámái a modernség nagy irodalmának díszletei között lezajlottak -, de mára már eléggé messze távolodtak attól, ami eközben az emberrel Kafka (Die Verwandlung), Valéry (Cahiers), Benn (Immer schweigender), József Attila (Eszmélet, "Költönk és Kora”) vagy Pynchon (Gravity's Rainbow) között valójában történt. Ha sorsára hagyjuk az emberi mibenléthez kötött irodalmiság új korszakküszöbének ezt az eddig ismeretlen tétekkel megjelenő kérdését, a kánonképződésre is csak a régi módon nyílnak majd látószögek. Vagyis nem marad-e az belül annak a sokat nem ígérő képletnek a horizontján, amely az interpretációs modelleket - némileg kiélezve - mindössze az Orgovány és a Solymosi Eszter vére közti térbe kényszeríti? Ez ugyan kétségkívül már nem a 19. század, de még mindig csak az 1930-as évek nem irodalmi okokból eltorzult irodalmi önmegértésének a világa. De ezzel a szorosabb értelemben vett irodalomtudománynak nincs dolga. A terepet itt különösebb lelkiismeret-furdalás nélkül engedheti át annak a kritikának, amelynek abban van a maga mindenkori múlandósága és szomorú esetlegessége, hogy a kulturális szereposztás őt rendelte oda e küzdelmek nem irodalmi érdekű megvívására.

A kánon mindezek értelmében csak akkor („tisztán”) irodalmi, ha a legritkábban bekövetkező eset érvényesül: akkor, ha a kánon nem egyéb, mint a nyelvművészeti minőségük alapján tartós megszólító erőt kifejtő művek sora, amely a babitsi értelemben az „idő és tér távolságain át” egymásnak felelő klasszikusok hatástörténeti párbeszédén alapul. ${ }^{35}$ Másképpen szólva akkor, amikor a kiemelkedő műalkotások a hatás, befogadás és utóélet tartós időbeliségében ismételten érdemesnek bizonyulnak arra, hogy újra meg újra elolvassák őket. ${ }^{36}$ Félreértés ne essék, attól még persze, hogy láthatatlan és hozzáférhetetlen, a belső

35 Vö. Babits Mihály, Az európai irodalom története, Szépirodalmi, Budapest, 1979, 12.

36 Babits meglepő éleslátása már 1934-ben a változással és egy olyan megújuló közléspotenciál meglétével magyarázza a tartós kánoni hatást, amely olyan kérdésekre is képes válaszolni, amilyenekkel a keletkezése idején a mủ nem is számolhatott: „Az Oedipus király például biztosan elevenebb, mint a közelmúlt évek idényeinek nem egy nagysikerü drámája, amelyet már el is feledtünk, vagy legalább elintéztünk magunkban végkép. Oedipust több mint kétezer év sem feledhette vagy intézhette el. [...] Mindannyiszor új lett előttünk, gazdagabb. Ki tudja, milyen gazdagság rejlik még benne, amiről eddig sejtelmünk sincs. Mindenesetre nem halt meg, hanem él, mert változik. És hat, ahogy csak az képes hatni, ami még változik és meg nem merevedett.” Uo., 461. Hangsúlyozhatnánk itt azt is, hogy a kánoni létnek még a „formamüvész" Babitsnál sem a véglegesen rögzült formai tökéletesség kisugárzó ereje a záloga, hanem az esztétikai tapasztalat ama változó igazságának - nyelvművészeti megvalósulástól elválaszthatatlan - érvényesülése, amely új válaszokban részesíti a mindenkori recepció önmegértésének igényeit. 
irodalmi kánonképződés poétikai folyamata az irodalmi jelenben sem szünik meg. Ami azt jelenti, hogy a jelenben ugyan nem alakul ki kötelezőnek vagy egyezményesnek tekinthető kortárs kánoni rend, de folyamatosan történik a képződése. Az irodalmi beszédmódok történetileg alakuló kánonját ugyanis a mindenkori nyelvnek való különbözö alkotói megfelelés mindig fennálló lehetőségei tartják „mozgásban”. Egy, a korábbiakból levezethetetlen, új nyelvmüvészeti történés okvetlenül újat és mást mond arról, hogy miért vagyunk mindig egy valamiként hangolt és valahogy értett világban otthon - vagy vagyunk idegenek benne. Egy-egy ilyen új műnek a hatása - úgyszólván „tetten érhetetlenül” - már akkor formálni kezdi az irodalmi jelen aktuális értékösszefüggéseit, mielőtt a hatás maga láthatóvá válnék. Legalábbis annak a - végső instanciának számító - recepciónak a számára, amely mindig csak utólagosan ismerheti fel hatástörténeti fordulatként a maga „egyidejüségében” annak idején még hozzáférhetetlen történést. És minthogy ez a történés valóban tetten érthetetlen, még a logikája sem valószínűsíthető. Goethe kivételével Nietzsche például már 1878-ban elavultnak látta a német klasszika alapítóit, ${ }^{37} \mathrm{~s}$ bár a modernség számára valóban egyikük műve sem bizonyult termékenyítonek vagy „folytathatónak”, az is igaz, hogy Keller, Stifter vagy Lichtenberg sem váltak olyan kiteljesíto „végbevivőkke” (Vollender), ${ }^{38}$ akik Nietzsche nézetéből klasszikusnak számíthatnának. E „nem „folytatódó” örökséghez hasonlóan ugyanakkor kalkulálhatatlan volt nálunk az a ma már jól belátható, 1990-es, 2000-es fordulat is, amely az addig irányértékként számon tartott Ottlik kimerülőfélben lévő hatástörténetét követte. Mindaz, ami az ezredforduló tájékán Esterházy, Térey, Bodor vagy részben még Nádas prózájában is az új irodalmi önmegértés korszakküszöbének közelségét jelezheti, nem tervezhető módon épül inkább Kosztolányi és Márai nyelv- és szubjektumszemléleti örökségére, mintsem a Krúdyéra (vagy kivált a Móricz Zsigmondéra): a Szindbád hazamegyhez képest a Zendülők már sokkal inkább Kosztolányi, mintsem Krúdy „folytatója” volt, miközben az így kiváltott fordulat most sem hívta elő Szentkuthy vagy Határ Győző írásmódját. Úgy is fogalmazhatnánk, ha történt kánoni változás a modern magyar epikában, az - csak így, utóbb látható módon - mindenekelőtt a Kosztolányi- és a Márai-próza nyelvművészeti, szubjektum- és nyelvszemléleti mintáinak többfajta újraírásában mutatkozik meg a legnyilvánvalóbban. Több küszöbhelyzetű mű szerzőjére nézve is találó lehet tehát Téreynek az a 2014-es nyilatkozata, mely szerint „Ottlik nagyon fontos alapító atya sokunk szemében, de nem ő vezeti a pennám, hanem akkor már inkább a közös elődök, közülük fóleg Kosztolányi, Márai”. ${ }^{39}$

37 Lásd az egykor kezdeményező Klopstock, Schiller, Lessing, Herder, Wieland értékelését: Nietzsche, $I$. m. 607-608.

38 Uo., 608.

39 „A hely önmagában mindig ártatlan.” Beszélgetés Térey Jánossal, http://www.irodalmijelen.hu/2014-aug-13-1441/ hely-onmagaban-mindig-artatlan) 
A kánonnak valójában mindig hasonló „kanonikus” irodalmi változások írják az egész folyamatot hordozó történetét. Az e folyamatot értelmező irodalomtörténet ezért - legyen ő maga akár a leggondosabb felderítője is a kánon peremére, sőt azon kívülre szorult értékeknek - nem válhat meg a müködésmódjához már mindig is hozzátartozó kanonizációs elemektől. Annál is kevésbé, mert még a „tisztán” irodalmi, külső érdekektől és befolyástól mentes - ugyanakkor a maga szabad poétikai terében is kölcsönös „erőhatások” jegyében alakuló - kánoni képződés sem demokratikus folyamat. Legalábbis amennyiben kánon egyáltalán csak akkor képes megszilárdulni, ha a nagyobb hatástörténeti erejü szövegek akár hosszabb távon, akár csak időlegesen - szükségszerűen kiszorítanak más szövegeket. Ez utóbbiak azonban nem „áldozatai” az előbbieknek, mindössze olyan tartományába kerülnek az irodalomnak, ahonnan egyikük elől sincs elzárva a recepció nyitottságába való visszatérés. 